\title{
MANAGING THE PROCESS OF TEACHING BY THE ADAPTIVE COMPUTER SYSTEM
}

\author{
Zdeňka KRIŠOV $\boldsymbol{A}^{*}$, Moravská vysoká škola Olomouc \\ Miroslav POKORNÝ, Moravská vysoká škola Olomouc
}

Přijato: 16. 2. 2015 / Akceptováno: 25. 5. 2015

Typ článku: Výzkum

DOI: $10.5507 /$ jtie.2015.004

Abstract: The aim of the current pedagogical research is to design and then verify in practice a holistic process of individual personalized education with the support of modern information technology. These complex adaptive models of teaching has striven to come as close to the needs and abilities of each student as possible in order to ensure the most efficient and fastest acquisition of required knowledge in the studied field. This paper presents a structure of the adaptive educational system which uses fuzzy expert modules to formalize the decision-making functions of a teacher and includes two adaptive loops which implement the adaptation of study materials according to the student's learning style and knowledge and modify his/her learning procedure.

Key words: adaptive educational system, learning style, evaluation, study materiál.

\section{ŘÍZENÍ PROCESU VÝUKY POMOCÍ ADAPTIVNÍHO POČÍTAČOVÉHO SYSTÉMU}

Resumé: Snahou současného pedagogického výzkum je navrhnout a poté prakticky overrit ucelený proces individuálni personalizované výuky s podporou modernich informačnich technologii. Tyto komplexni adaptivni modely výuky se co nejvíce snaži přibližit potřebám a schopnostem každého studenta s cílem zajistit co nejefektivnějši a nejrychlejšsi ziskání potřebných znalostí ve studované oblasti. V príspěvku je predstavena struktura adaptivního výukového systému, kterýobsahuje fuzzy expertni moduly kformalizaci rozhodovacich funkci pedagoga $i$ dvě adaptivní smyčky realizující přizpůsobení studijnich materiálů dle učebního stylu a znalostí studenta a modifikujici jeho postup učení.

Klíčová slova: adaptivní výukový systém, učební styl, hodnocení, studijní materiál.

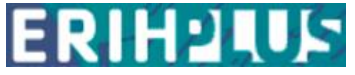

This journal was approved on 2015-04-23 according to ERIH PLUS criteria for inclusion.

\footnotetext{
*Autor pro korespondenci: zdenka.krisova@mvso.cz
} 


\section{1 Úvod}

Koncem 20. století dochází k rychlému rozvoji informačních a komunikačních technologií, což se projevilo i voblasti vzdělávání. S př́chodem internetu došlo ke značnému rozvoji elektronického vzdělávání, které využivá moderní informační technologie $\mathrm{v}$ procesu učení. Elektronické vzdělávání neboli e-learning přispívá k individualizaci výuky, kdy každý student preferuje svůj vlastní styl učení. Aby však výuka mohla být individuální, musí docházet $\mathrm{k}$ jejímu přizpůsobování, tedy $\mathrm{k}$ její adaptaci podle potřeb studenta.

Adaptivní výukový systém je systém, který se snaží přizpůsobit výukový proces individuálním vlastnostem a potřebám studentů. Jeho cílem je vytvořit takové prostředí, které žáka natolik motivuje, že je ochoten se učit sám bez nucení. Snaží se co nejvíce přizpůsobit studentovi, na jeho nesprávné reakce odpovědět jiným, pomalejším nebo podrobnějším výkladem, upozornit ho na chyby, přidat př́klady apod. Také studenta bude jednoznačně informovat o tom, co znát musí a v jaké míře, jestli už dostatečnou úroveň znalostí má, a jakou známku za ni dostane [10]. Adaptivní výuce se vzdáleně přibližuje Systém AHA - adaptivní hypermediální výukový systém [4], [16], který je založen na myšlence adaptivního webu. Web je přizpůsobován potřebám studenta na základě jeho chování při práci s hypermediálním systémem. Zavedení adaptace na základě stylů učení se věnuje Liu, který zdůrazňuje důležitost učebního stylu pro vzdělávání. Na základě rozdílů ve stylu učení studentů buduje adaptivní strategii pedagogického modelu pomocí sémantického webu a ontologie, definuje metadata spojená se styly učení studentů [11]. Bajraktarevic teoreticky zdůvodňuje, že soulad v učebním a vyučovacím stylu vede $\mathrm{k}$ lepšímu výkonu, dělá učení snadnější a zvyšuje efektivitu učení studentů [1]. Problematikou adaptivních systémů se již více než 20 let zabývá Peter Brusilovsky. Publikoval řadu prací o adaptivních hypermédiích a adaptivním webu a orientoval se na problematiku hypermediálních systémů, které se pokoušejí přizpůsobit stylu učení studenta [2].

Systém komplexního adaptivního modelu výuky, který je založený na zjištění vstupních charakteristik studenta, vytvoření vhodného adaptivního studijního materiálu a formulaci adaptivních algoritmů, vznikl na Pedagogické fakultě v Ostravě [10]. V adaptivních výukových systémech jsou uplatněny prvky umělé inteligence, které formalizují mentální modely zkušených pedagogů - expertů v oblasti vedení a řizení výukového procesu.

Příspěvek prezentuje relevantní části adaptivního výukového systému ADEPT (ADaptive Educational Programme Tool) a představuje jeho rozhodovací a adaptační procedury. Rozhodovací úlohy určení učebního stylu studenta a ohodnocení vhodnosti učebních materiálů podle jeho individuálního učebního stylu jsou realizovány s využitím nástrojů umělé inteligence - fuzzy-logických expertních systémů. Systém zahrnuje dvě adaptační procedury, z nichž první modifikuje strukturu učebního materiálu studenta v průběhu studia podle jeho aktuálních výsledků, druhá modifikuje průběžně model pro určení vhodných studijních materiálů podle jeho skutečného efektu v procesu učení. $\mathrm{V}$ př́spěvku jsou představeny principy systému ADAPT a výsledky simulačního ověření jeho funkcí. 


\section{Počítačový výukový systém ADEPT}

Základní struktura počítačového výukového systému ADEPT je uvedena na Obr. 1. Zjednodušené schéma je soustředěno hlavně na rozhodovací bloky a adaptační smyčky, které zajištují zvýšenou efektivitu systému v procesu výuky studenta.

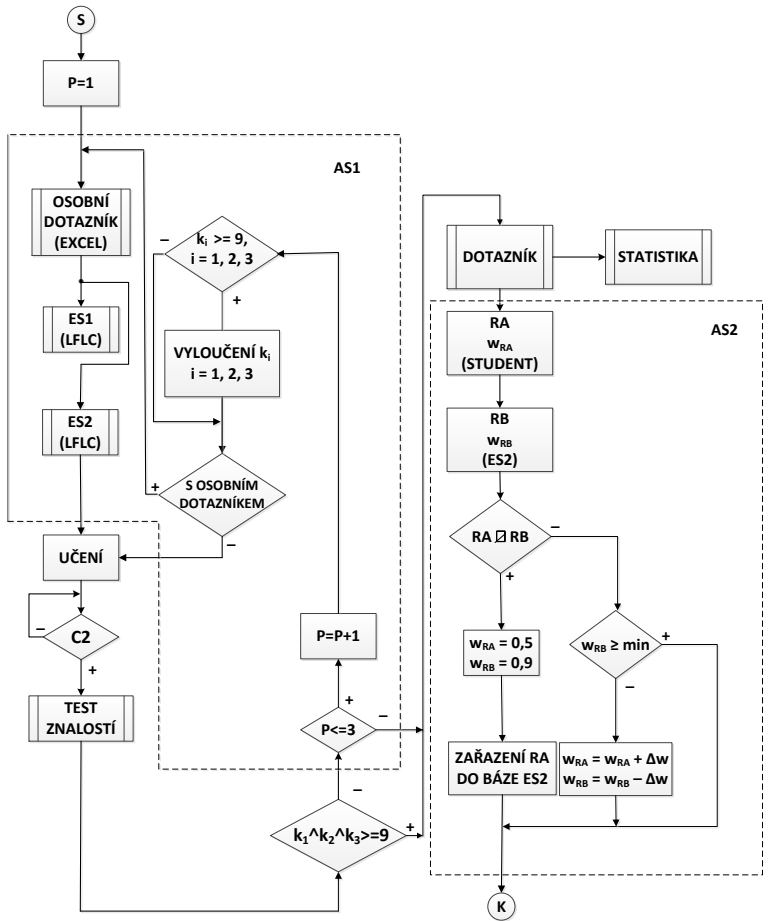

Obr 1: Schéma systému ADEPT

Základem systému jsou dva on-line rozhodovací bloky, využivající technologie fuzzy orientovaných expertních systémů [3]. Systém především doporučuje studentovi nejvhodnější verzi studijních materiálů podle jeho učebního stylu, na základě výsledků studia v jednotlivých cyklech studijní materiály v první adaptační smyčce modifikuje a provádí výslednou evaluaci studenta po ukončení jeho učení. Druhá adaptační smyčka modifikuje doporučování studijních materiálů na základě hodnocení kvality učení a posouzení vhodnosti vybraných učebních materiálů samotným studentem.

Před zahájením učení student vyplní OSOBNÍ DOTAZNÍK. Jeho výsledky jsou vstupními daty expertního systému ESI. Systém ESI diagnostikuje studentův učební styl (vstupní diagnostika). Určení učebního stylu studenta je důležitou informací o jeho vlastnostech.

Informace z dotazníku jsou dále vstupem pro expertní systém ES2, který doporučuje studentovi nevhodnější studijní materiály. Po ukončení procedury UČENÍ končí první cyklus studentova učení $(\mathrm{p}=1)$ a v bloku TEST ZNALOSTÍ jsou ohodnoceny jeho 
aktuální znalosti. Pokud nejsou studentovy znalosti dostatečné, pokračuje student pokud není vyčerpán předepsaný počet jeho učebních cyklů $(\mathrm{p}=3)$ - do druhého cyklu učení $(\mathrm{p}=2)$. Systém vstupuje do první adaptační smyčky $A S 1$, která na základě aktuální evaluace doporučí modifikaci studijních materiálů druhého učebního cyklu. Student dostává také možnost modifikovat materiály druhého cyklu učení novým vyplněním diagnostického dotazníku, kde může modifikovat (upřesnit) svůj názor na vlastnosti, určující jeho učební styl. Po ukončení druhého cyklu učení jsou opět posouzeny studentovy aktuální znalosti a v př́padě potřeby se učební cyklus vč. adaptace materiálů opět opakuje.

Jsou-li znalosti studenta dostatečné po ukončení cyklu učení nebo je vyčerpán předepsaný počet cyklů výuky, je učení ukončeno a systém vstupuje do fáze hodnocení průběhu učebních cyklů samotným studentem - blok DOTAZNíK. Jeho výsledky jsou jednak uloženy do datové báze STATISTIKA, jednak využity ve druhé adaptační smyčce AS2 pro úpravu modelu expertního systému ES2. Informace z bloku STATISTIKA jsou důležitou zpětnou vazbou, která bude sloužit ke zkvalitnění funkcí systému.

Detailní funkce expertních systémů ES1 a ES2 jsou spolu s popisem funkce adaptačních smyček $A S 1$ a $A S 2$ popsány v kap. 3 a kap. 4.

\section{Rozhodovací fuzzy moduly systému}

\subsection{Expertní systémy}

Expertní systémy jsou počítačové programy, které simulují rozhodovací činnost expertů při řešení velmi složitých, úzce problémově zaměřených úloh (Buckley, Siler, 2005). Je nesporné, že jejich funkce je s lidskou i umělou inteligencí velmi úzce spjata. Tyto systémy jsou založeny na myšlence převzetí znalostí od experta (tj. jeho znalostí objektivních i subjektivních) a jejich vhodné počítačové reprezentace, která by umožnila počítačovému programu využívat těchto znalostí zhruba stejným způsobem, jako jich využívá expert.

Nejrozšířenějším typem expertních systémů jsou expertní systémy diagnostické. Jsou určeny pro efektivní interpretaci dat $\mathrm{s}$ cílem určit, která $\mathrm{z}$ hypotéz ( $\mathrm{z}$ předem stanovené konečné množiny hypotéz) nejlépe koresponduje s aktuálními daty týkajícími se konkrétního řešeného prípadu. Diagnostický expertní systém, jehož struktura je uvedena na Obr. 2 [9], byl použit ve výukovém systému ADEPT.

Jádro takového systému (viz Obr. 2) tvoří rrídicí (inferenční) mechanizmus, který operacemi nad bází znalostí na základě aktuálních dat - dotazu upřesňuje (aktualizuje) obecný model a vyvozuje odpověd' - závěr.

Báze znalostí jako obecný model chování studované soustavy (v našem př́padě studenta) je tvořena expertními znalostmi, které jsou formalizovány vhodnou reprezentací.

Uživatelsky významnou částí expertního systému je vysvětlovací podsystém. Ten poskytuje informace o konkrétním postupu, jímž bylo dosaženo závěru. Tak může uživatel sám posoudit kvalitu báze znalostí i inference a výsledek odvození př́padně dodatečně modifikovat.

Lze říci, že cílem expertního systému je dosahovat obdobně kvalitních závěrů při řešení složitých problémů, jako by stejný problém řešil člověk-expert v daném oboru (v našem případě zkušený pedagog). Expertní systémy jsou schopny efektivně využívat eventuální nejistoty jak v bázi znalostí, tak v bázi dat. 


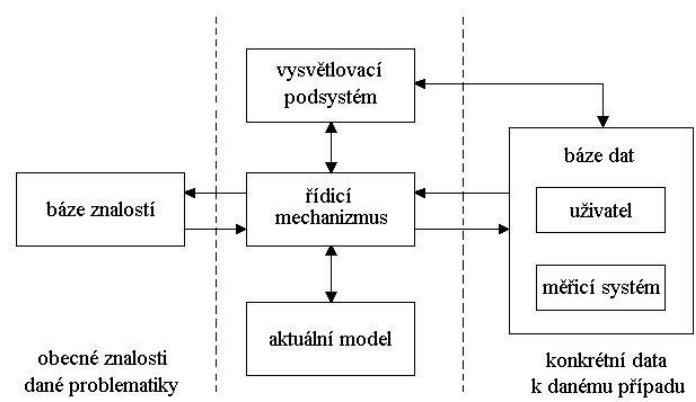

Obr. 2. Schéma diagnostického expertního systému

Znalosti jsou nejčastěji reprezentovány formou podmíněných IF-THEN pravidel a formalizace jejich neurčitostí pomocí aparátu fuzzy množinové matematiky. Jako inferenční (vyvozovací) mechanizmy využívají tyto modely přístupy jazykové fuzzy logiky [3], [14].

Fuzzy expertní systémy používají pro formalizaci znalostí podmíněných IF-THEN pravidel ve formě

IF (předpoklad, antecedent) THEN (diosledek, konsekvent)

Antecedenty i konsekventy pravidel jsou vágní fuzzy výroky - jejich pravdivostní hodnota leží v intervalu $\langle 0,1\rangle$. Jedná se o Mamdaniho pravidlo, jehož interpretace

IF ( $x$ is $\left.A_{l}\right)$ THEN ( $y$ is $\left.B_{l}\right)$

vyjadřuje kauzální vztah mezi jazykovými proměnnými $x$ a $y$. Jinými slovy - jestliže jazyková proměnná $x$ nabude své jazykové hodnoty $A_{l}$, důsledkem je stav, kdy jiná jazyková proměnná y nabude své jazykové hodnoty $B_{l}$.

Pravidlo (2) je nejjednodušším popisem chování (jazykovým modelem) soustavy $\mathrm{s}$ jedním vstupem a jedním výstupem. V praxi pracujeme se soustavami s více vstupy a pravidlo má pak tvar:

$I F\left[x_{1}\right.$ is $A\left(x_{1}\right)$ and $x_{2}$ is $A\left(x_{2}\right)$ and

$\ldots$ and $x_{n}$ is $A\left(x_{n}\right)$ ] THEN [ $y$ is $B(y)$ ]

Soubor takových pravidel pak popisuje chování reálné soustavy a tvoří její pravidlový jazykový fuzzy model. Antecedenty pravidel obsahují obvykle všechny kombinace jazykových hodnot vstupních proměnných, odpovídající velikost výstupní proměnné v konsekventu je určena expertem.

Tvar výstupní modifikované fuzzy množiny $\mathrm{B}_{0}$ při dosazení konkrétních hodnot proměnných $x_{1}$ až $x_{n}$ získáme vyvozovacím algoritmem, využívajícím zákonů fuzzy logiky. Vyvozovací algoritmy se liší interpretacemi svých fuzzy-logických spojek (Buckley, Siler, 2005). Pro vyvození závěrů v příspěvku použitých expertních systémech je použit mechanismus typu Mamdani. Tvar funkce prŕislušnosti výsledné fuzzy množiny $B(y)$ je dán vztahem:

$$
B(y)=\max _{1<r<m}\left(\min \left(B_{r}(y), \min _{1<j<n}\left(\operatorname{Cons}\left(A_{j} x, A_{r j} x\right)\right)\right)\right)
$$


Vysvětlení této operace, nazývané fuzzy kompozice, lze získat např. v [3], [14].

\subsection{Expertní systém ES1}

Expertní systém ES1 slouží k diagnostice učebního stylu studenta před začátkem resp. v procesu jeho učení [8].

Učební styl je postup učení, který student používá $\mathrm{v}$ určitém období života ve většině situací pedagogického typu. Je do jisté míry nezávislý na obsahu učení. Vzniká na vrozeném základě (kognitivní styl) a rozvíjí se spolupůsobením vnitřních i vnějších vlivů. Vlivů, které bezprostředně působí na učební styl studenta, je velké množství [10]. Prezentovaný výukový systém ADEPT je zaměřen na individuální výuku prostřednictvím e-learningu, a proto $\mathrm{k}$ diagnostice učebního stylu studenta jsou zvoleny ty vlastnosti, které jsou v e-learningovém prostředí využitelné a které lze bezprostředně využit $\mathrm{k}$ ř́zení elektronického učení. Učební styl studenta je $\mathrm{v}$ jazykovém modelu expertního systému $E S 1$ určován na základě těchto charakteristik - vstupních jazykových proměnných: sociální aspekt, zpuisob zpracování informace, smyslové vnimání a postup učení (viz Tab. 1).

\begin{tabular}{|c|c|c|c|c|}
\hline $\begin{array}{l}\text { Jazyková } \\
\text { proměnná }\end{array}$ & Id & $\begin{array}{c}\text { Rozsah } \\
\text { univerza }\end{array}$ & $\begin{array}{c}\text { Jazykové } \\
\text { hodnoty }\end{array}$ & Id \\
\hline \multirow{2}{*}{$\begin{array}{l}\text { SOCIÁLNÍ } \\
\text { ASPEKT }\end{array}$} & \multirow{2}{*}{ SA } & \multirow{2}{*}[0,15]{} & INTROVERT & INT \\
\hline & & & EXTROVERT & EXT \\
\hline \multirow{2}{*}{$\begin{array}{l}\text { ZPŮSOB } \\
\text { ZPRACOVÁNÍ } \\
\text { INFORMACE }\end{array}$} & \multirow{2}{*}{ ZZI } & \multirow{2}{*}[0,15]{} & TEORETIK & TEO \\
\hline & & & PRAKTIK & PRA \\
\hline \multirow{2}{*}{$\begin{array}{l}\text { SMYSLOVÉ } \\
\text { VNÍMÁNÍ }\end{array}$} & \multirow{2}{*}{ SV } & \multirow{2}{*}[0,15]{} & GRAFICKÉ & GRA \\
\hline & & & VERBÁLNÍ & VER \\
\hline \multirow{2}{*}{ POSTUP UČENÍ } & \multirow{2}{*}{$\mathrm{PU}$} & \multirow{2}{*}[0,15]{} & HOLISTA & HOL \\
\hline & & & DETAILISTA & DET \\
\hline
\end{tabular}

Tab. 1. Vstupni jazykové proměnné modulu ES1

SA - Sociální aspekt charakterizuje způsob zapojení do okolního sociálního prostředí, který student při učení preferuje. Na základě této vlastnosti systém ESI rozlišuje dva typy studentů [12]: 
- Introvert dává přednost samostatnému učení nebo pracuje ve dvojici učí se s kolegou či kamarádem. Kontakt s větší skupinou nevyhledává, raději poslouchá, než aby se zapojil do konverzace.

Extrovert je zaměřen na kontakt s lidmi a realitou, učí se rád ve větší skupině studentů, debatuje se spolužáky, vyhledává spolupráci s nimi.

ZZI - Způsob zpracování informace rozlišuje preferenci teorie nebo praktického experimentování. Na základě této vlastnosti dělí systém ESI studenty do dvou skupin [18]:

- Teoretik preferuje teoretické odvozování a důkladné přemýšlení o nově nabytých vědomostech.

- Praktik je experimentátor, který si nabyté vědomosti raději aktivně vyzkouší, nejlépe v praxi. Pro každou informaci hledá způsob, jak s ní něco udělat, zjištuje k čemu je užitečná.

Na základě kombinace dvou předchozích vlastností studenta - sociálního aspektu a způsobu zpracování informace systém ESI definuje čtyři typy studentů: aktivní typ, reflexivní typ, aktivně-reflexivní typ a reflexivně-aktivní typ. Vychází ze skutečnosti, že komplexní psychické procesy, které přeměňují vnímanou informaci na znalost, se skládají ze dvou kategorií - aktivního experimentování a reflexivního pozorování [6].

- Aktivní typ se mnoho nenaučí z přednášek, protože předávají informace pasivně. Lépe se učí $\mathrm{v}$ situacích, které umožňují skupinovou práci a aktivní experimentování.

- Reflexivni typ vyžaduje situace, které mu poskytnou př́ležitost přemýšlet o prezentované informaci. Je to spíše teoretik a raději pracuje sám nebo príípadně $\mathrm{s}$ jednou další osobou.

- Aktivně-reflexivní typ - teoretik, který uprednostňuje skupinovou práci (extrovert).

- Reflexivně-aktivní typ - praktik (experimentátor), který raději pracuje sám (introvert).

SV - Smyslové vnímání popisuje, která forma informací studentovi nejvíce vyhovuje. Charakterizuje, kterým smyslem student nejlépe vnímá, jakou formu informací nejlépe pochopí a zapamatuje si ji. Systém vychází z názoru, že studenti získávají informace vizualizací (obrázky, symboly, diagramy) nebo sluchově (pomocí zvuků a slov) ES1 rozlišuje dva typy studentů [6]:

- Grafický typ, který si pamatuje nejlépe to, co vidí - např. obrázky, diagramy, schematické animace, grafy, mapy, různé symbolické šipky, hierarchie a další nástroje, které $\mathrm{v}$ grafické podobě ukazují např. kroky, kterými se bude učitel $v$ hodině zabývat. Informaci, která je studentům tohoto typu předávána pouze ústně, mohou zapomenout.

- Verbálni typ, který si pamatuje hodně z toho, co slyší, a ještě více z toho, co slyší a následně sám interpretuje. Studentům tohoto typu vyhovují diskuze, ze kterých se mnoho naučí. Dávají přednost ústnímu vysvětlování před vizuální demonstrací. Učí se efektivně tím, že vysvětlují něco ostatním nebo někoho poslouchají. 
PU - Postup učení rozlišuje, jak rozsáhlou informaci je student schopen zpracovat najednou. Systém ESI rozlišuje dva typy studentů [17]:

- Holistický typ má tendenci vnímat situaci v celku, globálně. Zaměřuje se na velké části obecných informací, od kterých se postupně propracovává $\mathrm{k}$ detailům. Analýza detailů mu činí potíže.

- Detailistický (analytický) typ se zaměřuje na malé části konkrétních informací, ze kterých postupně skládá obraz celku. Má problém porozumět situaci v globálním rozměru.

Aktuální číselné hodnoty všech čtyř vstupních proměnných systému ES1 jsou získány vyhodnocením studentova dotazníku. Jeho zdrojem jsou práce [7], [12], [15], [17], [18]. K otázkám dotazníku byla přiložena škála, vyjadřující míru souhlasu s daným výrokem (a, spíše a, b, spiše b). Jednotlivé odpovědi jsou ohodnoceny body od 0 do 3 . Každá ze sledovaných vlastností je testována na pěti otázkách, proto student může za své odpovědi získat hodnocení v rozmezí 0 až 15 bodů.

Uvedený př́stup $\mathrm{k}$ rozhodnutí o učebním stylu (typu) studenta je formalizován v jazykovém modelu expertního systému $E S l$ třemi výstupními jazykovými proměnnými s jazykovými hodnotami, popsanými v Tab. 2.

\begin{tabular}{|l|l|c|l|}
\hline $\begin{array}{l}\text { Jazyková } \\
\text { proměnná }\end{array}$ & Id & Jazyková hodnota & Id \\
\hline \multirow{2}{*}{$\begin{array}{l}\text { Typ } \\
\text { REFLEXNI } \\
\text { nebo AKTIVNI }\end{array}$} & \multirow{2}{*}{ REF/AKT } & REFLEXIVNÍ & REF \\
\cline { 3 - 4 } & & $\begin{array}{c}\text { REFLEXIVNÉ- } \\
\text { AKTIVNÍ }\end{array}$ & RA \\
\cline { 3 - 4 } & $\begin{array}{c}\text { AKTIVNÉ- } \\
\text { REFLEXIVNÍ }\end{array}$ & AR \\
\cline { 3 - 4 } & AKTIVNÍ & AKT \\
\hline $\begin{array}{l}\text { Typ } \\
\text { VIZUÁLNÍ } \\
\text { nebo } \\
\text { VERBALNI }\end{array}$ & VIZ/SLO & VIZUÁLNÍ & VIZ \\
\hline $\begin{array}{l}\text { Typ HOLISTA } \\
\text { nebo } \\
\text { DETAILISTA }\end{array}$ & \multirow{2}{*}{ HOL/DET } & SLOVNÍ & SLO \\
\cline { 3 - 4 } & & DETALISTA & HOL \\
\hline
\end{tabular}

Tab. 2. Výstupní jazykové proměnné modulu ESI

Báze znalostí systému ES1 je tvořena soustavou podmíněných IF-THEN pravidel (3), jejichž podmínkové části představují všechny kombinace jazykových hodnot vstupních proměnných. Jednotlivé kombinace byly expertně ohodnoceny přiřazením př́islušných jazykových hodnot výstupních proměnných. Např. pravidlo $R_{l}$ má tvar

$R_{l}$ : IF (SA is INT) and (ZZI is TEO) and (SV is GRA) and (PU is HOL) THEN

(REF/AKT is REF) and (VIZ/SLO is VIZ) and (HOL/DET is HOL) a formalizuje tuto znalost:

Jestliže se student raději uči individuálně, teoreticky, lépe si pamatuje to, co vidí, a při učení uprednostňuje velké shluky informací, pak se jedná o studenta reflexivního, vizuálního a holistu. 
Expertní systém ES1 je implementován ve vývojovém prostředí LFLC (Linguistic Fuzz Logic Controller) [5]. Jazykové hodnoty vstupních a výstupních proměnných pravidlového fuzzy modelu jsou reprezentovány fuzzy množinami (viz Obr. 4)

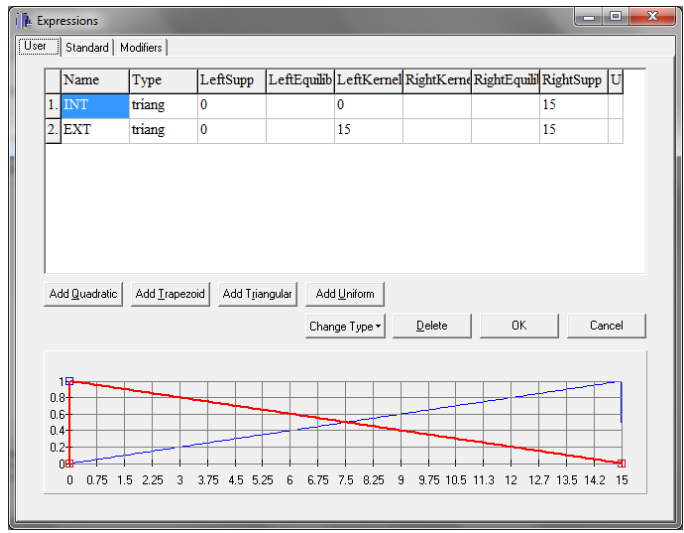

Obr. 4. Obraz LFLC - vstupní jazykové proměnné modelu ES1

Aproximativní vyvození výstupních jazykových hodnot modelu je provedeno metodou Mamdani (4). Výstupem jsou učební styly, ohodnocené stupněm možnosti $<0,1>$ podle aktuálních hodnot vstupních proměnných (viz Obr. 5).

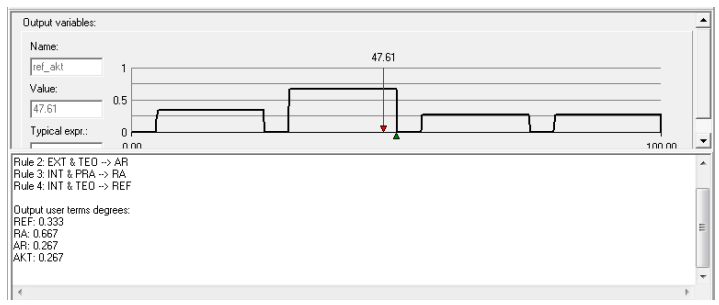

Obr. 5. Obraz LFLC - ohodnocené výstupni hodnoty učebnich stylü ES1

\subsection{Expertní systém ES2}

Expertní systém ES2 navazuje na systém ES1. Po vyhodnocení učebního stylu studenta systémem ES1 expertní systém ES2 doporučí studentovi konkrétní studijní materiál, podle něhož se má učit. Vychází přitom ze studentova učebního stylu - opět $\mathrm{z}$ vyhodnoceného studentova dotazníku).

Jazykový model expertního systému ES2 má 4 vstupní jazykové proměnné (viz Tab. 1) a jednu výstupní jazykovou proměnnou s 16 jazykovými hodnotami, které reprezentují verze doporučovaných studijních materiálů (viz Tab. 3). 


\begin{tabular}{|l|l|l|}
\hline Proměnná & Id & \multicolumn{1}{|c|}{ Jazykové hodnoty (studijní typy) } \\
\hline \multirow{5}{*}{} & V1 & vizuální, reflexivní a holista \\
\cline { 2 - 3 } & V2 & vizuální, reflexivní a detailista \\
\cline { 2 - 3 } & V3 & vizuální, aktivně-reflexivní a holista \\
\cline { 2 - 3 } & V4 & vizuální, aktivně-reflexivní a detailista \\
\cline { 2 - 3 } & V5 & vizuální, reflexivně-aktivní a holista \\
\cline { 2 - 3 } & V6 & vizuální, reflexivně-aktivní a detailista \\
\cline { 2 - 3 } VERZE & V7 & vizuální, aktivní a holista \\
\cline { 2 - 3 } & V8 & vizuální, aktivní a detailista \\
\cline { 2 - 3 } & V9 & verbální, reflexivní a holista \\
\cline { 2 - 3 } & V10 & verbální, reflexivní a detailista \\
\cline { 2 - 3 } & V11 & verbálního, aktivně-reflexivní a holista \\
\cline { 2 - 3 } & V12 & verbální, aktivně-reflexivní a detailista \\
\cline { 2 - 3 } & V13 & verbální, reflexivně-aktivní a holista \\
\cline { 2 - 3 } & V14 & verbální, reflexivně-aktivní a detailista \\
\cline { 2 - 3 } & V15 & verbální, aktivní a holista \\
\cline { 2 - 3 } & V16 & verbální, aktivní a detailista \\
\hline
\end{tabular}

Tab. 3. Výstupní jazyková proměnná modulu ES2

Bázi znalostí expertního systému ES2 tvoří soubor IF-THEN pravidel (3), jejichž podmínkové části představují všechny kombinace jazykových hodnot vstupních proměnných. Jednotlivé kombinace jsou expertně ohodnoceny přiřazením prř́slušných jazykových hodnot výstupní proměnné. Např. pravidlo $R_{l}$ má tvar:

$R_{l}$ IF (SV is GRA) and (ZZI is TEO) and (SA is INT) and (PU is HOL) THEN (VERZE is V1) a formalizuje tuto znalost:

Jestliže si student lépe pamatuje to, co vidí, raději se uči teoreticky, individuálně a při učení upřednostn̆uje velké shluky informací, pak studentovi doporučuji verzi V1 studijnich materiálù.

V tomto pravidle se tedy jedná o studenta vizuálního, reflexivního (teoretika a introverta) a holistu, jemuž jsou dle Tab. 3 určeny studijní materiály verze V1.

Expertní systém ES2 je implementován ve vývojovém prostředí LFLC (Linguistic Fuzzy Logic Controller) [5]. Fuzzy množiny jeho jazykových hodnot vstupních proměnných ukazuje Obr. 6 . 


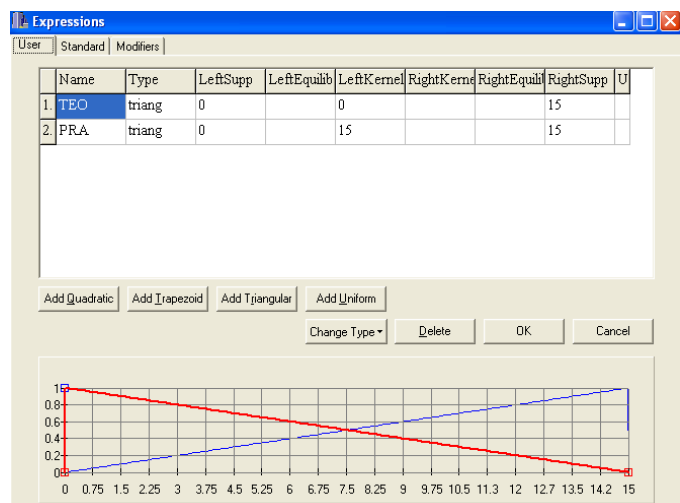

Obr. 6. Obraz LFLC - vstupní jazykové proměnné modelu ES2

Aproximativní vyvození výstupních jazykových hodnot modelu je opět provedeno metodou Mamdani (4). Výstupem jsou varianty učebních materiálů ohodnocené stupněm vhodnosti pro daného studenta $\mathrm{z}$ interavalu $<0,1>$ dle aktuálních hodnot vstupních proměnných (viz Obr. 7).

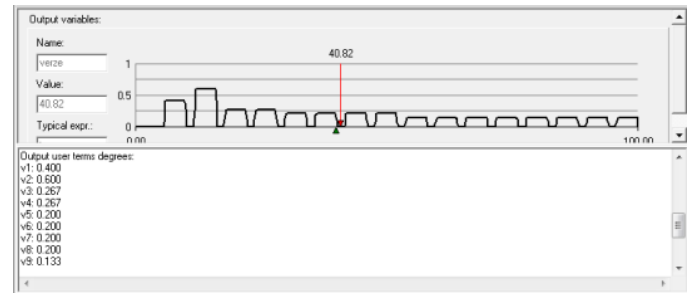

Obr. 7. Obraz LFLC - ohodnocené verze studijnich materiálů ES2

Konkrétní verze doporučovaných studijních materiálů V1 - V16 závisí na konkrétním vyučovaném předmětu. Jazykový model systému ES2 je orientovaný na výuku předmětu Informatika a řeší téma Císelné soustavy.

\section{Adaptivní procedury systému}

\subsection{Adaptace postupu učení studenta AS1}

Po evaluaci aktuální úrovně znalostí studenta $\mathrm{v}$ daném $p$ - tém cyklu učení je $\mathrm{v}$ bloku TEST ZNALOSTÍ (viz Obr. 1) vyhodnoceno, zda jsou znalosti studenta dostatečné ve všech (zde ve třech kapitolách učiva, označených $k_{1}, k_{2}, k_{3}$ ). Pokud ano, systém předloží studentovi k vyplnění výstupní formuláŕ (DOTAZNÍK). Pokud ne, je provedena kontrola vyčerpání povoleného počtu cyklů učení a pokud $\mathrm{P}<=3$ systém pokračuje určením těch kapitol studia, kde jsou výsledky nedostatečné. Jsou vybrány potřebné učební materiály pro další cyklus učení a studentovi předloženy ke studiu. Současně je mu poskytnuta možnost opakovaného vyplnění dotazníku (OSOBNÍ DATAZNÍK), kdy může student reagovat na vhodnost doporučených materiálů modifikací odpovědí 
na položené otázky. Tím adaptační smyčka $A S 1$ modifikuje materiály pro další cyklus učení.

\subsection{Adaptace expertního modulu ES2}

Iniciační jazykový model expertního modulu ES2, deklarovaný expertem, je v průběhu exploatace systému ADEPT modifikován (učen) rozšiřováním počtu jeho pravidel, tedy zvětšováním rozsahu znalostí používaných k rozhodování o vhodnosti jednotlivých 16-ti typů studijních materiálů (V1 - V16) pro konkrétního studenta (viz Obr. 7). Jazykový model obsahuje 16 IF-THEN pravidel, z nichž $i$-té pravidlo doporučuje ve svém konsekventu materiál $\mathrm{Vi}, i=1, \ldots, 16$.

Po ukončení posledního cyklu učení vyplní student formulář DOTAZNÍK, v němž potvrdí nebo změní pořadí vhodnosti materiálů, které mu doporučil systém ES2. Pokud student nevyužije ke studiu materiál, který mu systém vybral (materiál s nejvyšším ohodnocením) a po úvaze jej nahradí jiným, pak je vygenerováno nové pravidlo, které tuto skutečnost (znalost) reflektuje.

Pokud takové pravidlo ještě $\mathrm{v}$ bázi neexistuje, jedná se o nové pravidlo $(R A)$ a s nižší váhou svého vlivu $(\mathrm{w}=0,5)$ je zařazeno do báze $E S 2$.

Pokud takové pravidlo v bázi již existuje, je tato skutečnost zohledněna jen zvýšením váhy jeho vlivu $(\mathrm{w}=\mathrm{w}+\Delta \mathrm{w})$ a současně snížením váhy původního pravidla. Konkrétně pravidlu $R A$ je zvýšena váha dle $W_{R A}=W_{R A}+\Delta$ a původnímu pravidlu $R B$ váha snížena dle $W_{R B}=W_{R B}-\Delta$ (viz Obr. 1). Po předepsaném počtu výskytů může nové pravidlo $R A$ dosáhnout $\mathrm{v}$ bázi plného vlivu $(\mathrm{w}=1)$. Současně je stejným způsobem snižována váha vlivu pravidla iniciačního (stanoveného expertem), tak může být původnímu pravidlu $R B$ v bázi váha snížena až na $w=0,25$. Touto adaptační procedurou je realizována funkce učení pravidlového modelu $E S 2$.

\section{Simulační ověření rozhodovacích procedur}

Efektivita navržených fuzzy modulů je ověrována v programovém prostředí MatlabSimulink, který je s LFLC kompatibilní. Systém Simulink je nadstavba MATLABu pro simulaci a modelování dynamických systémů [13].

\section{Expertní systém ES1}

Simulační výpočty $\mathrm{v}$ adaptivním výukovém systému provádíme tak, že vyplníme dotazník ES1 (OSOBNÍ DOTAZNÍK), jehož strojovým vyhodnocením dostáváme konkrétní číselné hodnoty čtyř proměnných SA, ZZI, SV a PU. Tyto hodnoty jsou vstupy do modulu ES1. ES1 vyvozuje odpovídající hodnoty tří výstupních proměnných. Pro simulační pokusy jsou konkrétní vstupní hodnoty uvedeny v Tab. 4.

\begin{tabular}{|c|c|c|c|c|}
\hline Č́slo pokusu & SA & ZZI & SV & PU \\
\hline 1 & 3 & 11 & 7 & 12 \\
\hline 2 & 12 & 10 & 9 & 4 \\
\hline
\end{tabular}

Tab. 4. Hodnoty vstupnich proměnných ESI

Pokus 1 simuluje studenta, který se raději učí individuálně a rád vše vyzkouší. Lépe si pamatuje to, co vidí a a informace zpracovává po menších částech. Systém správně vyvodil, že jde o studenta spíše reflexivně-aktivního, vizuálního a detailistu (viz tab. 5). 
Pokus 2 simuluje situaci, kdy student raději pracuje ve skupině formou pokusů a omylů. Lépe si pamatuje to, co slyší nebo čte, a zaměřuje se na velké části obecných informací, aby získal celkový př̀ehled. Systém správně vyvodil, že takový student je spíše aktivní, verbální a holista. (viz tab. 5).

\begin{tabular}{|c|c|c|c|c|c|c|c|c|}
\hline \multirow{3}{*}{ Pokus } & \multicolumn{7}{|c|}{ Výstupní jazykové hodnoty } \\
\cline { 2 - 9 } & \multicolumn{9}{|c|}{ REF/AKT } & \multicolumn{2}{c|}{ VIZ/SLO } & \multicolumn{2}{c|}{ HOL/DET } \\
\cline { 2 - 9 } & REF & AKT & RA & AR & VIZ & SLO & HOL & DET \\
\hline 1 & 0,27 & 0,2 & 0,73 & 0,2 & 0,53 & 0,47 & 0,2 & 0,8 \\
\hline 2 & 0,2 & 0,67 & 0,2 & 0,33 & 0,4 & 0,6 & 0,73 & 0,27 \\
\hline
\end{tabular}

Tab. 5. Expertni ohodnoceni typologie učebniho stylu studenta

Výsledky diagnostiky stylů učení studenta $\mathrm{v}$ obou pokusech odpovídají předpokladům. Ukazují významnou vlastnost systému ESI - spojité ohodnocení jednotlivých učebních stylů pro konkrétního studenta $\mathrm{v}$ intervalu $<0,1>\mathrm{s}$ možností interpretace výstupů formou uspořádání. Takový globální výstup má vyšši informační obsah než pouhý odhad učebního stylu studenta jeho prriřazením do ostrého číselného intervalu.

\section{Expertní systém ES2}

Studijní materiály, které byly vytvořeny pro simulační ověření, řeší problematiku číselných soustav (jedno z témat předmětu Informatika). Materiály jsou rozděleny do tř́ kapitol: Problematika číselných soustav, Převod mezi číselnými soustavami a Aritmetické operace v binární soustavě. Obecně bychom však v ES2 mohli využít studijní materiály libovolného prírodovědného předmětu, které by byly pro potřeby systému ES2 adekvátně upraveny.

Vstupem pro simulaci systému ES2 jsou stejné číselné hodnoty jako pro expertní systém $E S 1$ (viz Tab. 4). Expertní systém $E S 2$ vyvozuje ohodnocení všech 16 jazykových hodnot výstupní proměnné VERZE (verzí studijních materiálů) s ohledem na konkrétní osoby studentů z pokusů 1 a 2 . Pro simulační pokusy jsou konkrétní vstupní hodnoty uvedeny v Tab. 4, expertním systémem ES2 vyvozené a ohodnocené hodnoty výstupní proměnné obsahuje Tab. 6 .

\begin{tabular}{|c|c|c|l|}
\hline $\begin{array}{c}\text { Č́slo } \\
\text { pokusu }\end{array}$ & $\begin{array}{l}\text { Ohodnocení } \\
\text { vlastností }\end{array}$ & $\begin{array}{l}\text { Pořadí } \\
\text { doporučení }\end{array}$ & Doporučené verze \\
\hline \multirow{5}{*}{1} & $\mathbf{0 , 5 3}$ & $\mathbf{1}$ & V6 \\
\cline { 2 - 4 } & 0,47 & 2 & V14 \\
\cline { 2 - 4 } & 0,27 & 3 & V2, V10 \\
\cline { 2 - 4 } & 0,20 & 4 & $\begin{array}{l}\text { V1, V3, V4, V5, V7, } \\
\text { V8, V9, V11, V12, } \\
\text { V13, V15, V16 }\end{array}$ \\
\hline \multirow{5}{*}{2} & $\mathbf{0 , 6 0}$ & $\mathbf{1}$ & V15 \\
\cline { 2 - 4 } & 0,40 & 2 & V7 \\
\cline { 2 - 4 } & 0,33 & 3 & V3, V11 \\
\cline { 2 - 4 } & 0,27 & 4 & V4, V8, V12, V16 \\
\cline { 2 - 4 } & 0,20 & 5 & $\begin{array}{l}\text { V1, V2, V5, V6, V9, } \\
\text { V10, V13, V14 }\end{array}$ \\
\hline
\end{tabular}

Tab. 6. Doporučení pořadí studijních materiálů systémem ES2 
Pokus 1 vybírá studijní materiály pro studenta spíše reflexivně-aktivního, vizuálního a detailistu (viz Tab. 5). Systém tedy správně určil jako nejvhodnější materiál verzi V6 (viz Tab. 6). Zbývající verze studijních materiálů mají ohodnocení nižší, verzi V14 může student také pro doplnění svých znalostí využít (ohodnocení tohoto materiálu 0,47), zbývající verze materiálů jsou pro studenta tohoto typu spíše nepodstatné.

Pokus 2 určuje studijní materiály pro studenta spíše aktivního, verbálního a holistu (viz Tab. 5). Systém ES2 správně doporučuje jako nejvhodnější materiál verzi V15 (viz Tab. 6). Student může využít i verzi V7 k doplnění svých znalostí (ohodnocení této verze je již však nižší, konkrétně 0,4$)$. Ostatní studijní materiály jsou pro studenta tohoto typu spíše nepodstatné (jejich ohodnocení je menší než 0,4 ).

Výsledky vyvození doporučeného pořadí studijních materiálů expertním systémem ES2 v obou simulačních pokusech odpovídají předpokladům.

\section{Závěr}

Snahou současného pedagogického výzkum je vytvořit adaptivní počítačový výukový systém, který by se co nejvíce přibližil potřebám a schopnostem každého studenta s cílem zajistit co nejefektivnější a nejrychlejší získání potřebných znalostí ve studované oblasti. Základem jsou moderní informační technologie, které využívají nekonvenční metody umělé inteligence $\mathrm{k}$ abstraktní strojové formalizaci mentálních modelů zkušených pedagogů, vedoucí ke strojové reprezentaci jejich sofistikovaných výukových metod a postupů.

Struktura prezentovaného adaptivního výukového systému ADEPT zahrnuje dva on-line fuzzy-logické expertní systémy. Oba expertní systémy počítačově formalizují mentální rozhodovací funkce zkušeného pedagoga. První určuje učební styl studenta, druhý doporučuje nejvhodnější studijní materiál pro studenta konkrétního studijního typu. Systém ADEPT dále obsahuje dva adaptační moduly. První řeší problém průběžné modifikace doporučeného studijního materiálu na základě studijních výsledků v jednotlivých cyklech učení. Druhý modul úloha řeší problém průběžného učení báze znalostí expertního systému pro doporučování struktury studijního materiálu podle informací od studenta a jeho návrhu na modifikaci učebního postupu.

Systém ADEPT je implementován ve vývojových prostředích LFLC a MATLAB. Provedené simulační úlohy ukazují výsledky rozhodovacích funkcí obou expertních systémů pro dva různé studijní typy uživatelů. Výsledky simulací potvrzují správnost jejich funkce.

\section{Poděkování}

Tento př́spěvek vznikl s finanční podporou a $\mathrm{v}$ rámci řešení projektu GAČR P403/12/1811 „Vývoj nekonvenčních metod manažerského rozhodování v podnikové ekonomii a veřejné ekonomice“ jako dokumentace př́nosů dizertační práce Metody umělé inteligence ve vzdělávacím procesu.

\section{Literatura}

Bajraktarevic, N., Hall, W., \& P. Fullick. (2003). Incorporating learning styles in hypermedia environment: Empirical evaluation. Proceedings of the Workshop on Adaptive Hypermedia and Adaptive Web-Based System. pp. 41-52. Nottingham, UK. Brusilovsky, P. (2003). From Adaptive Hypermedia to the Adaptive Web. Mench \& Computer. Interaktion in Bewegung. pp. 21-24. Stuttgart: B. G. Teubner. 
Buckley, J. J. \& W. Siler. (2005). Fuzzy Expert Systems and Fuzzy Reasoning. Theory and Applications. United States: John Wiley \& Sons Inc.

Bureš, M., \& JELÍNEK, I. (2004). Adaptivní webové systémy v e-learningu. In Belcom'04. Praha: ČVUT, s. 223-226.

Dvořák, A., Habiballa, H., Novák V. \& Pavliska. (2003). The concept of LFLC 2000 - its specificity, realization and power of applications. Computers in Industry. Vol. 51, No 3, pp. 269-280.

Felder, R. M. \& Silverman, L.K. (1988). Learning and Teaching Styles in Engineering Education. In Journal of Engineering Education, Vol. 78, No 7, pp. 674-681.

Felder, R. M. \& Soloman, B. A. (2004). Index of Learning Styles. Retrieved June 25, 2013. from http://www.ncsu.edu/felder-public/ILSpage.html.

Krišová, Z. \& M. Pokorný. (2013). Diagnostics of a student's learning style with the use of modern information technologies. In The New Educational Rewue, Vol 34, No 4. pp. 174-187. Torun, Polsko: Wydawnictwo Adam Marszalek.

Pokorný, M. \& Krišová. (2011). Teorie systémů 2. Olomouc: MVŠO, s. 86.

Kostolanyová, K. (2012). Teorie adaptivního e-learningu. Ostrava: Ostravská univerzita. s. 118.

Liu, H. (Ed.). (2010). Pedagogical Strategy Model in Adaptive Learning Systém Focusing on Learning Styles. Entertainment for Eduacation. Digital Techniques and Systems. Lecture Notes in Computer Science. Spring-Verlag Berlin: Heidelberg, pp. 156164.

Mareš, J. (2004). E-learning a individualni styly učeni. Československá psychologie. Ročník 4, Č́́slo 3. s. 250.

Matlab - The MathWorks-MATLAB and Simulink for Technical Computing. (2012). Retrieved July, 7. from http://www.mahworks.com.

Novák, V., Perfiliova, I. \& J. Močkoř. (1999). Mathematical Principles of Fuzzy Logic. Engineering and Computer Science. vol. 517. Boston, USA: Kluwer.

Novotný, S. (2010). Individualization of teaching through e-learning: Development of Students' Learning Profile Questionnaire. Theoretical and Practical Aspects of Distance Learning. pp 105-116. Katowice, Polsko: Studio Noa.

Paramythis, A. \& Loidl-Reisinger, S. (2004). Adaptive Learning Environments and eLearning Standards. In Electronic Journal of E-learning. Vol. 2, No 2.

Riding, R. J. \& Cheema, I. (1991). Cognitive styles - an overview and integration. In Educational psychology. Vol. 11, No 3-4. pp 193-215.

Sternberg, R. J. \& Grigorenko, E. L. (1999). Genetics and intelligence. In Journal of American Academy of Child and Adolescent Psychiatry, Vol. 38. pp 486-488. 